medRxiv preprint doi: $h t t p s: / / d o i . o r g / 10.1101 / 2022.02 .23 .22271303$; this version posted February 26, 2022. The copyright holder for this preprint (which was not certified by peer review) is the author/funder, who has granted medRxiv a license to display the preprint in

It is made available under a CC-BY 4.0 International license .

$1 \quad$ Research article

2

3

4

\title{
Changes in the quality of cancer care as assessed through performance indicators during the first wave of the COVID-19 pandemic in 2020: a Scoping Review
}

Changes in the quality of cancer care during the first wave of the COVID-19 pandemic in

12 Ana Sofia Carvalho ${ }^{1,2 *}, \mathrm{MD}$

13 Óscar Brito Fernandes ${ }^{1}, \mathrm{MSc}, \mathrm{MEd}$

14 Mats de Lange ${ }^{1}$, MD

15 Hester Lingsma ${ }^{2}, \mathrm{PhD}$

16 Niek Klazinga ${ }^{1}$, MD, $\mathrm{PhD}$

17 Dionne Kringos ${ }^{1}$, MSc, $\mathrm{PhD}$

$19{ }^{1}$ Department of Public and Occupational Health, Amsterdam UMC, University of Amsterdam, 20 Amsterdam Public Health research institute, Amsterdam, the Netherlands

$21{ }^{2}$ Department of Public Health, Erasmus MC - University Medical Centre Rotterdam, The Netherlands 22

$23 *$ Corresponding author:

24 Ana Sofia Carvalho

25 Department of Public Health

26 Erasmus MC - University Medical Centre Rotterdam

27 The Netherlands 


\section{Abstract}

33 Objectives: Summarize performance indicators used in the literature to evaluate the impact of the

34 COVID-19 pandemic on cancer care (January-June 2020), and to assess changes in the quality of care as assessed via selected indicators.

Methods: Scoping review. Indicators and their reported trends were collated following the cancer care pathway.

Results: Database searches retrieved 6277 articles, 838 articles met the inclusion criteria, and 135 articles were included after full-text screening, from which 917 indicators were retrieved. Indicators assessing the diagnostic process showed a decreasing trend: from 33 indicators reporting on screening, $30(91 \%)$ signalled a decrease during the pandemic ( $\mathrm{n}=30$ indicators, 91\%). A reduction was also observed in the number of diagnostic procedures $(n=64,58 \%)$ and in the diagnoses $(n=130,89 \%)$. The proportion of diagnoses in the emergency setting and waiting times showed an increasing trend $(\mathrm{n}=8$, $89 \%$ and $\mathrm{n}=14,56 \%$, respectively). Nine indicators (64\%) showed stability in cancer stages distribution. A decreasing trend in the proportion of earliest stage cancers was reported by $63 \%$ of indicators $(\mathrm{n}=9)$, and $70 \%(\mathrm{n}=43)$ of indicators showed an increasing trend in the proportion of advanced-stage cancers. Indicators reflecting the treatment process signalled a reduction in the number of procedures: $79 \%(\mathrm{n}=82)$ of indicators concerning surgeries, $72 \%(\mathrm{n}=41)$ of indicators assessing trends in radiotherapy, and $93 \%(n=40)$ of indicators related to systemic therapies. Modifications in cancer treatment were frequently reported: $64 \%(n=195)$ of indicators revealed changes in treatment. Ten indicators $(83 \%)$ signalled a decreasing number of hospital admissions.

52 Conclusion: Health systems struggled to ensure continuity of cancer care. As this pandemic keeps evolving, the trends reported over the first 6 months of 2020 provide an argument to monitor these changes closely. This information needs to be transparent, standardised, and timely, allowing to monitor quality and outcomes of care during crises and inform policy responses. 
medRxiv preprint doi: https://doi.org/10.1101/2022.02.23.22271303; this version posted February 26, 2022. The copyright holder for this preprint (which was not certified by peer review) is the author/funder, who has granted medRxiv a license to display the preprint in

perpetuity.
It is made available under a CC-BY 4.0 International license.

56

57 Keywords:

$58 \quad 1-$ Quality of Health Care $[\mathrm{MeSH}]$

$59 \quad 2-\quad$ Quality Indicators, Health Care $[\mathrm{MeSH}]$

60 3- Continuity of Patient Care $[\mathrm{MeSH}]$

61 4- Cancer care

62 5- COVID-19

63

64 


\section{Introduction}

The COVID-19 outbreak was declared a public health emergency of international concern by the World Health Organization on the $30^{\text {th }}$ of January, 2020 [1]. Since the beginning of the pandemic, global health systems struggled to cope with the high numbers of patients infected with SARS-CoV2, while maintaining adequate care for non-COVID patients [2].

Cancer comprises a high burden to populations and health systems, being the second cause of death globally [3], and in Organisation for Economic Co-operation and Development (OECD) countries [4]. The COVID-19 pandemic has widely affected cancer care delivery. Substantial declines in the number of cancer diagnoses have been reported in the Netherlands [5,6], Spain [7], Belgium [8], and Denmark [9]. While trying to minimize the risk of COVID-19 disease in cancer patients, changes in practice were pursued by oncologists, according to each setting's capacity and recommendations released by oncology societies [10-12] . Changes in the treatment prescribed were reported, by delaying, changing treatment modality, duration, or mode of delivery [13].

Improving cancer care was already on the international health agenda prior to this pandemic, namely in the 2030 Agenda for Sustainable Development adopted in 2015 at the United Nations Sustainable Development Summit [14], in the Resolution "Cancer prevention and control in the context of an integrated approach" approved in 2017 by the World Health Assembly [15]. At the same time, systematic efforts to capture the outcomes of cancer care globally via cancer registries are in place such as the CONCORD study [16,17]. The OECD reports on cancer care as part of its Health at a Glance Series [4] and European Union (joint) actions have taken place [18]. During the COVID-19 pandemic, efforts continued to be pursued to improve prevention, diagnostics, treatment, and the quality of life of cancer patients, among others with the launch of the "Europe's Beating Cancer Plan" in November 2020 [19] and initiatives to monitor and report upon inequalities, such as the European Cancer Inequalities Registry [20] and the launch of the European Commission's Knowledge Centre on Cancer [21]. These efforts are necessary to tackle the cancer crisis and to address the backlog this pandemic is creating [22-24]. 
medRxiv preprint doi: https://doi.org/10.1101/2022.02.23.22271303; this version posted February 26, 2022. The copyright holder for this preprint (which was not certified by peer review) is the author/funder, who has granted medRxiv a license to display the preprint in It is made available under a CC-BY 4.0 International license.

91 One key area that needs strengthening is the development of performance indicators, its

92 standardization, and timely collection by health systems data infrastructures [25], to efficiently inform

93 on changes in the quality of care provided, allowing for comparisons within and between countries'

94 health systems. Although improving outcomes like 5-year survival is the ultimate aim, for guiding

95 health care delivery systems towards that goal, process and cancer-pathway based information is 96 essential.

97 The literature published on the consequences of the pandemic on cancer care is vast, therefore 98 assessing its impact requires a structured approach. This scoping review is part of a larger project, 99 which focuses on performance indicators on the care for non-communicable diseases (NCD). This 100 study aims to provide a systematic summary of cancer care performance indicators used in the 101 literature, regarding various cancers, across the care pathway, from early detection to outcomes, and 102 with an international coverage. Additionally, we set out to assess the main trends of the changes in the 103 quality of cancer care during the first wave of the COVID-19 pandemic, from January to June 2020, 104 by collecting and collating the performance indicators' trends across the cancer care pathway. 
medRxiv preprint doi: https://doi.org/10.1101/2022.02.23.22271303; this version posted February $26,2022$. The copyright holder for this preprint (which was not certified by peer review) is the author/funder, who has granted medRxiv a license to display the preprint in It is made available under a CC-BY 4.0 International license.

107 Methods

108 We conducted a scoping review, following Arksey and O’Malley methodological framework [26],

109 further developed by Levac et al [27]. Given the lack of standardized methods across countries for

110 data collection on health care system performance assessment and their translation to indicators

$111[25,28]$, a scoping review methodology allows to map the large sums and heterogeneity of literature

112 available $[27,29,30]$ and to identify key concepts present in the literature [30], namely cancer care

113 performance indicators. It also enables the reporting of emerging evidence [29], to summarize, and

114 communicate findings [26], including trends revealed by indicators. The PRISMA extension for scoping reviews [31] was used for reporting (S1 Table).

\section{Eligibility criteria of studies}

118 We considered the following inclusion criteria: 1) studies using empirical data on the use of health services in OECD countries, 2) studies that described health outcomes and/or performance indicators related with NCD during the COVID-19 pandemic, 3) original journal articles using quantitative or qualitative methods (cohort studies, case-control, cross-sectional, case reports, systematic reviews, surveys, and meta-analyses). Studies were excluded if they did not provide empirical data on health services and NCD, namely: 1) editorials and commentaries, 2) prediction models, 3) clinical case reports; 4) diseases management or health services organization guidelines, 5) studies about the impact on healthcare workers, patients diagnosed with COVID-19, children, or pregnant women; 6) studies primarily performed in non-OECD countries. No limitations were set regarding language or year of publication.

\section{Information sources}

130 MEDLINE and Embase databases were selected to search for this study, given the large number of 131 articles and their comprehensive coverage of the literature on health services delivery. Pilot searches 
medRxiv preprint doi: https://doi.org/10.1101/2022.02.23.22271303; this version posted February 26,2022 . The copyright holder for this preprint (which was not certified by peer review) is the author/funder, who has granted medRxiv a license to display the preprint in

It is made available under a CC-BY 4.0 International license.

132 were conducted to identify a list of suitable search terms. An experienced medical information

133 specialist was consulted to improve the search strategy, which was refined with discussion among co-

134 authors. The comprehensive search included search terms grouped by key concepts (COVID-19,

135 pandemic, non-communicable disease, chronic disease, performance indicator, healthcare quality,

136 healthcare utilization, healthcare delivery and other closely related terms). The search was adapted to

137 both databases and conducted by the information specialist on 17-03-2021. The full search strategy for

138 Embase can be found in S2 Doc. Duplicates were removed using EndNote software. Additional articles

139 of relevance were added by hand-searching the reference lists of the included studies.

140

141 Selection of sources of evidence

142 Titles and abstracts screening was performed independently by two researchers (ASC, OBF) using

143 Rayyan [32]. Studies considered relevant were exported to a spreadsheet to support full-text screening.

144 For this study, only articles related to cancer care were analysed. Full-text screening was performed 145 independently by two researchers (ASC, MdL). The reason for the exclusion of articles was recorded 146 at this point, and both researchers agreed on the excluded studies. In case of doubt, the other co-authors 147 were consulted.

Data extraction

150 Data extracted was collated in a spreadsheet (S3 Table) piloted on 15 studies. Prior to extracting data 151 from all studies, two researchers (ASC, MdL) compared data collected from 10 selected articles with the objective of enhancing data extraction consistency among researchers. Then, data was charted independently by ASC and MdL. Extracted data included information on generic and methodological aspects of the article (e.g., authors, title, setting) and information about the indicators collected (e.g., indicator title, and data inclusion/exclusion considerations). For every indicator, we identified the trend reported in the articles (increase/decrease/stable), if any. 
medRxiv preprint doi: https://doi.org/10.1101/2022.02.23.22271303; this version posted February 26, 2022. The copyright holder for this preprint (which was not certified by peer review) is the author/funder, who has granted medRxiv a license to display the preprint in It is made available under a CC-BY 4.0 International license.

157

\section{Synthesis of results}

159 We grouped and categorised the indicators following clinical reasoning. These categories were

160 organized according to the different phases of the cancer care pathway: early detection, diagnosis,

161 treatment, and outcomes. Quantitative indicators' trends were collated, and the percentage of indicators

162 reporting each trend (increase/decrease/stable) was computed for each category. This evidence is

163 presented in the text of this study and in a diagram informing about each phase of the cancer care

164 pathway. Qualitative information extracted from surveys is presented in the text, and it was not

165 considered to compute trends. In the category "changes in treatment" quantitative indicators and

166 qualitative information were grouped and categorized according to clinical reasoning to present an

167 overview of the modifications in cancer treatment reported. 
medRxiv preprint doi: https://doi.org/10.1101/2022.02.23.22271303; this version posted February 26, 2022. The copyright holder for this preprint (which was not certified by peer review) is the author/funder, who has granted medRxiv a license to display the preprint in

perpetuity.
It is made available under a CC-BY 4.0 International license.

\section{Results}

171 Database searches retrieved 6277 articles. Of these articles, 838 met the inclusion criteria, from which

172197 articles on cancer care were identified. Eight records were identified via hand-searching. After

173 full-text screening, 135 articles were included in this study (Fig. 1).

174 


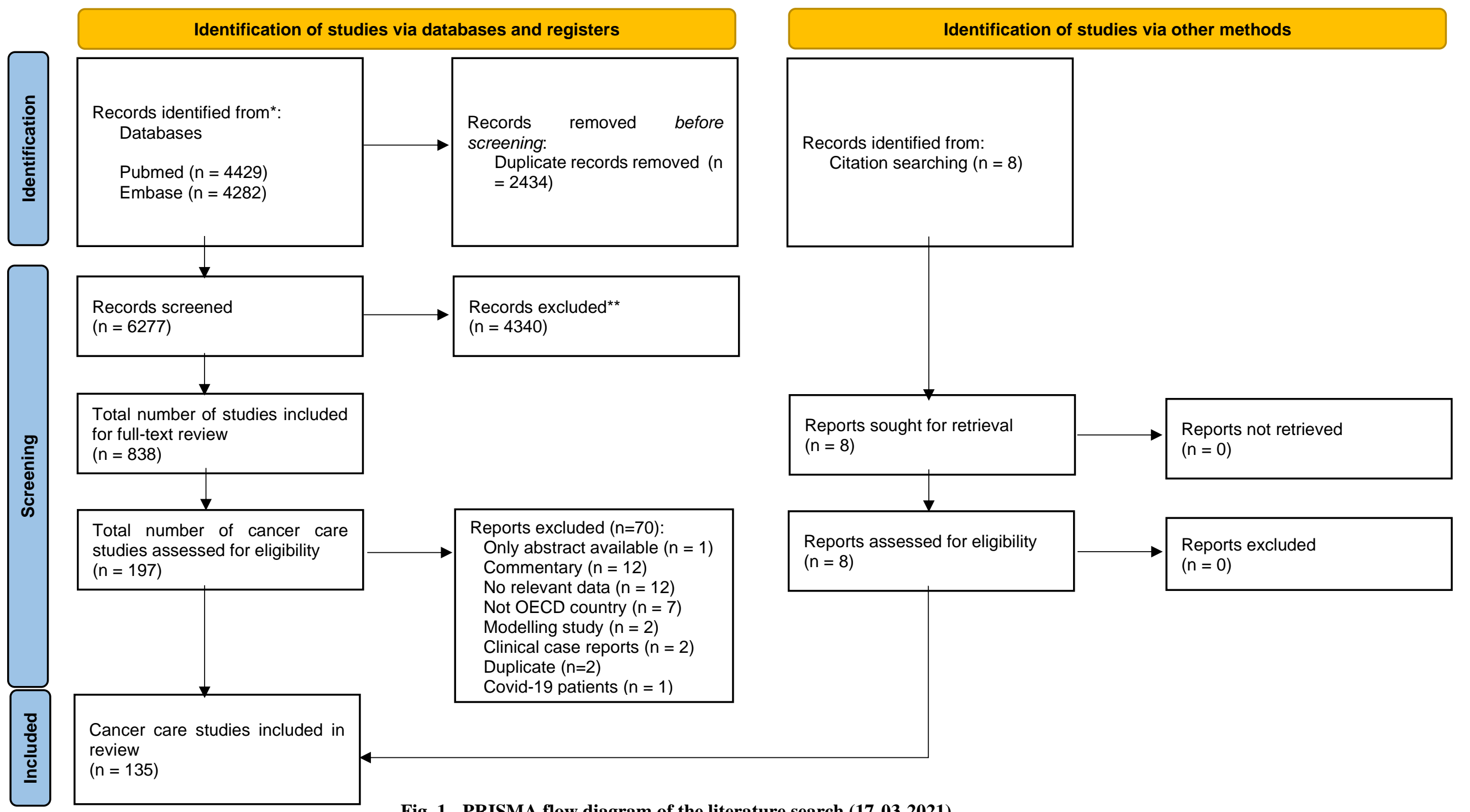


medRxiv preprint doi: https://doi.org/10.1101/2022.02.23.22271303; this version posted February 26, 2022. The copyright holder for this preprint (which was not certified by peer review) is the author/funder, who has granted medRxiv a license to display the preprint in

It is made available under a CC-BY 4.0 International license.

\section{General characteristics of the included articles}

210 In total, 135 studies were included, reporting on 94 countries (S4 Table). Of these studies, 26 (19\%)

211 provided information on multiple countries, from which $14(10 \%)$ specified all the countries included.

212 Of those, $8(6 \%)$ included non-OECD countries. Most of the studies including more than one country 213 were surveys $(n=23,89 \%)$. The most frequent countries reported on were Italy $(n=36,29 \%)$, US $(n=32$,

$21426 \%)$ and UK (n=27, 22\%) (Fig. 2). Most articles used a retrospective cohort design ( $\mathrm{n}=82,61 \%)$,

215 followed by surveys $(n=44,33 \%)$. Surveys were often directed to health professionals $(n=37 / 44,84 \%)$

216 and to patients $(n=6 / 44,14 \%)$ to a lesser extent. Other study designs that were applied included

217 prospective cohorts $(n=5)$, observational retrospective cohorts $(n=3)$, and a combination of prospective

218 and retrospective cohort $(\mathrm{n}=1)$. Studies reported indicators' trends during the first phase of the COVID-

21919 pandemic (from January to June 2020) and, in some cases, after the (in many countries

220 implemented) lockdown period (from May to October 2020). The magnitude of each indicator in 2020

221 was compared with its magnitude in the same period of $2019(\mathrm{n}=51,38 \%)$, to a period immediately

222 before ( $\mathrm{n}=33,24 \%)$ or to the average of the same period in previous years (ranging from 2017 to 2019$)$

$223(n=26,19 \%)$.

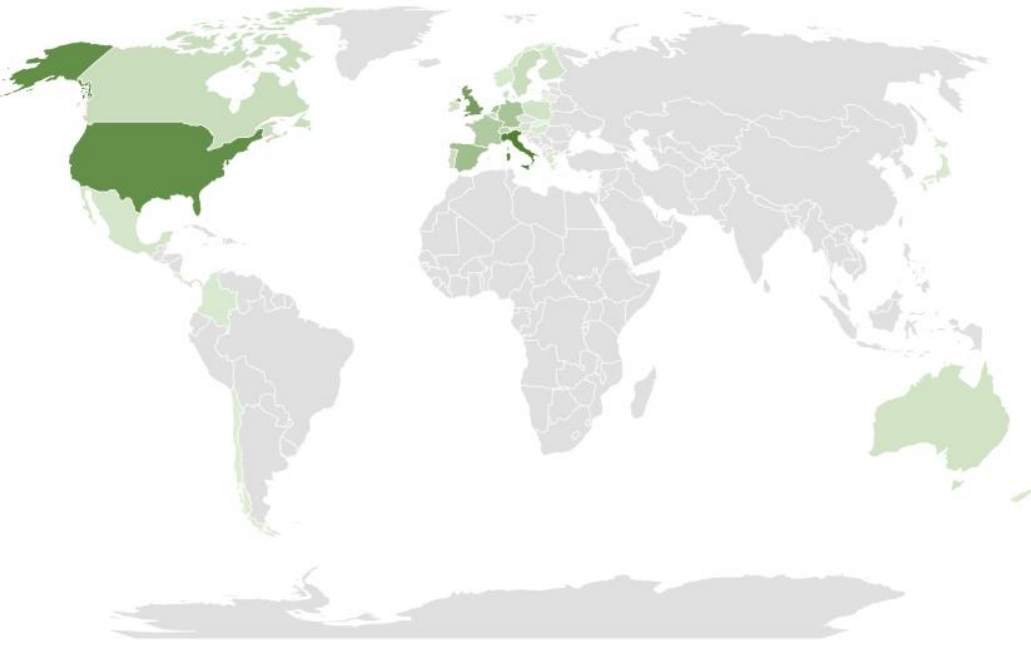

Fig. $2-$ OECD countries reported on, color-graded according to the number of papers $(n=122$ articles; $90 \%$ of included articles). 
medRxiv preprint doi: https://doi.org/10.1101/2022.02.23.22271303; this version posted February 26, 2022. The copyright holder for this preprint (which was not certified by peer review) is the author/funder, who has granted medRxiv a license to display the preprint in

perpetuity.
It is made available under a CC-BY 4.0 International license .

\section{Cancer Care Indicators}

241 A total of 917 quantitative indicators from 91 articles were retrieved and grouped into categories (Table $2421)$.

243 Table 1 - Cancer care indicators' categories retrieved in the literature review

\begin{tabular}{|l}
\hline Early detection \\
\hline Number of screening procedures \\
Early diagnosis and predisposition exams \\
Screening detection rates
\end{tabular}

Diagnosis and staging

Number of diagnostic, surveillance, and staging exams/procedures

Number of cancer diagnoses

Delay in access to diagnostic procedures

Cancer detection rate

Proportion of urgent/emergent referrals and procedures

Changes in cancer staging

Clinical severity at diagnosis

Treatment

Number of referrals / first encounters

Outpatient volume

Number of treatments

Cancer-related surgeries \& loco-regional therapies

Radiotherapy treatments

Systemic anticancer therapy

Delay in treatment

Changes in treatment

Number of visits and admissions in hospital

Virtual multidisciplinary meetings

Telemedicine utilization

\section{Outcomes}

Surgical and procedures outcome measures

Mortality

Note: A total of 338 indicators were not included in the analysis since they were too specific to be grouped into the defined 
medRxiv preprint doi: https://doi.org/10.1101/2022.02.23.22271303; this version posted February 26,2022 . The copyright holder for this preprint (which was not certified by peer review) is the author/funder, who has granted medRxiv a license to display the preprint in

It is made available under a CC-BY 4.0 International license.

247 The first stage of the care pathway looks at early detection. Regarding the "number of screening and 248 other early diagnosis procedures", a total of 33 indicators from 13 articles [33-45] have been reported.

249 Most indicators on the number of screening procedures signaled a decreasing trend $(n=30,91 \%)$, 250 namely in US, UK, and Italy. One international survey answered by physicians [46] (including Italy, 251 Iran, Spain, UK, US, China, Denmark, Sweden, and Switzerland) reported the suspension of breast screening programs in all countries, except 2. Only one American paper [38] addressed cervical cancer screening, showing a decrease in number of screenings during stay-at-home order, compared with 2019. Three articles $[35,39,42]$ addressed colorectal cancer screening, from US, UK and Spain and have also revealed a reduction when compared with previous year.

Seven papers [33,34,36-38,40,42] reported on "early diagnosis and predisposition exams", namely: screening visit for prostate cancer (US), gBRCA testing (Italy), HPV tests rate, low-dose computed tomography and prostate-specific antigen measurement (all from the US). All these indicators have shown a decreasing trend in the number of diagnostic procedures. US and Italy. Most of the indicators $(n=9,75 \%)$ showed an increase in screening detection rates. These included an increase in high-risk adenomas and colorectal cancer detection rates during the lockdown period, along with a decrease in low-risk adenoma detection rates in one Italian study [47].

The next stage of the care pathway focuses on diagnosis and staging. The "number of diagnostic, surveillance and staging procedures" was reported in 17 articles [41,43-45,48-60] (from the UK, Italy, US, France, Australia, the Netherlands, Turkey, Ireland, and Slovenia), comprising a total of 90 indicators. Most of those indicators $(\mathrm{n}=58,64 \%)$ showed a decreasing trend in the number of procedures, namely cystoscopy, diagnostic mammograms, breast cancer wire-guided biopsy, gastroscopy, colonoscopy, computed tomography (CT), magnetic resonance imaging (MRI), and endoscopic retrograde cholangiopancreatography. 
medRxiv preprint doi: https://doi.org/10.1101/2022.02.23.22271303; this version posted February 26, 2022. The copyright holder for this preprint (which was not certified by peer review) is the author/funder, who has granted medRxiv a license to display the preprint in

It is made available under a CC-BY 4.0 International license.

272 A total of 147 indicators from 35 articles [9,35,39,47,48,52,54,55,59-83] reported on the "number of

273 cancer diagnosis". Most of these indicators $(n=130,89 \%)$ signalled a decrease in the number of cancer

274 diagnoses. Data came from registries in the Netherlands, Denmark, Germany, and Italy, cytology

275 laboratories, tumor boards numbers, and administrative sources. One international survey to

276 laboratories from 23 countries [66] showed an absolute reduction in the number of cytological samples

277 regarding all anatomic sites.

278 Five studies [37,55,67,75,82] (from the US, UK, France, and Italy) addressed the number of cancer 279 diagnoses after the lockdown period (10 indicators). Three of these indicators (30\%) showed a higher 280 number of diagnoses, when compared with the period of lockdown.

281 Five surveys [84-88] reported "delays concerning different aspects of cancer diagnostics". One 282 international survey [85] focusing on colorectal cancer care, with professionals from 84 countries, 283 reported delays in radiologic exams and endoscopic procedures. Other surveys mentioned limited 284 access to hospital facilities (Italy) [89], delays in tissue diagnosis (UK) [88], delays in diagnostics of 285 patients with neuroendocrine tumors (Germany, Austria, Switzerland) [87], and genetic testing or counseling (US) [86]. The other two articles [43,90] addressed the delays in access to diagnostics, comprising a total of 9 quantitative indicators, from which $8(89 \%)$ signalled an increase in the waiting time to diagnostic procedures.

The "cancer detection rate in referrals and diagnostic exams" was assessed in 5 articles, from UK [59,91], Italy [48], Ireland [43], and one international survey of 23 laboratories worldwide [66]. The 13 indicators collected signalled an increasing trend in cancer detection rate in 9 indicators $(69 \%)$. The survey reported an increase of $5.5 \%$ in the malignancy rate in nongynecological samples, when compared with the corresponding period in 2019. reported on the proportion of "urgent/emergent referrals and procedures". Most of these $(n=14,56 \%)$ showed an increase in the proportion of urgent procedures (endoscopy and colonoscopies), diagnosis in emergency setting or operations that followed an emergency admission. 
medRxiv preprint doi: https://doi.org/10.1101/2022.02.23.22271303; this version posted February 26,2022 . The copyright holder for this preprint (which was not certified by peer review) is the author/funder, who has granted medRxiv a license to display the preprint in

It is made available under a CC-BY 4.0 International license.

298 The indicators that reported on "changes in cancer staging" were grouped in 3 different categories:

299 general staging indicators (14 indicators from 8 articles $[75,77,81,94-98])$, proportion of earliest-stage

300 cancers (35 indicators from 9 articles [41,71,81,99-104]), and proportion of advanced-stage cancers

301 (61 indicators from 17 articles [39,57,63,66,77,79,87,92,93,95-102]).

302 Most of the general staging indicators $(n=9,64 \%)$ showed stability in cancer stages distribution at 303 diagnosis, when comparing the pre- and post-lockdown periods (data from Italy, US, UK, France, US, 304 and Portugal). These indicators included stages of gynecological cancer, breast cancer, lung cancer, and hepatocellular carcinoma. With respect to the proportion of earliest stage cancers, most of the indicators $(\mathrm{n}=9,63 \%)$ showed a lower proportion of these cancers when compared with pre-pandemic period, $9(26 \%)$ signalled a stable trend, and $4(11 \%)$ showed an increasing trend. From the indicators reporting on the proportion of advanced-stage cancers, 43 (70\%) showed an increasing trend in this proportion after the beginning of the pandemic, $14(23 \%)$ signalled a stable proportion, and 4 (7\%) reported a decreasing trend.

311 Fourteen indicators from 7 articles [41,47,57,69,97,100,105] evaluated the "clinical severity at diagnosis", which included symptoms, scores, and biomarkers. The majority (n=8 indicators, 57\%)

313 showed patients presenting in a more severe clinical condition than before the pandemic, namely in 314 US (endometrial cancer), Portugal (hepatocellular carcinoma), Italy, and Turkey (colorectal cancer).

315 The following stage of the care pathway reported on is cancer treatment. A total of 41 indicators 316 (from 9 articles $[35,60,65,72,91,96,103,106,107]$ ) reported on the "number of cancer patients' 317 referrals". Most of the indicators $(37,90 \%)$ signalled a decrease in the number of first encounters for 318 oncological examination, namely in Slovenia, UK, US, France, Spain, and the Netherlands. Four 319 surveys (from UK [88], US, Italy [108] and one international study [109] reported a decrease in the 320 number of new referrals.

321 A total of 47 indicators were identified from 14 articles $322[35,42,44,52,55,60,65,90,91,93,96,106,110,111]$ regarding the outpatient care of patients diagnosed 323 with cancer. Of these indicators, $46(93 \%)$ showed a decrease in the number of outpatient visits (in 
medRxiv preprint doi: https://doi.org/10.1101/2022.02.23.22271303; this version posted February 26, 2022. The copyright holder for this preprint (which was not certified by peer review) is the author/funder, who has granted medRxiv a license to display the preprint in It is made available under a CC-BY 4.0 International license .

324 Korea, US, France, UK, Spain, Slovenia, and Italy). Thirteen surveys $[13,46,70,86,87,89,108,112$

325 117] disclosed information concerning outpatient care. Ten were answered by oncologists and 3 were 326 answered by patients. The latter studies reported consequences on treatment or follow-up 327 (Netherlands) [114], namely treatment adjustment, postponement, delay, or discontinuation; delay in routine or follow-up clinic appointment (US) [86] and postponements of physician appointments (Germany). A substantial percentage of physicians reported cancellation or deferral of follow-up visits.

Regarding the "volume of cancer treatment", indicators regarding the 3 main therapeutic components were reported: surgeries and loco-regional therapies, radiotherapy, and systemic therapy.

Concerning surgeries and loco-regional therapies, 106 indicators were identified from 30 articles [42,48-51,55,62,65,65,75,81,90,92-94,97-99,101-103,111,118-125]. Of those, 82 indicators (79\%) showed a reduction in the number of treatment procedures, namely in Italy, France, Germany, Ireland, Netherlands, Spain, Turkey, UK, US, Australia, and in 1 international study. Nineteen articles were surveys directed to physicians $[46,58,70,78,84,85,88,90,108,115,126-134]$, out of which 8 were international. All have shown significant reductions in surgical activity regarding different cancers. identified. Most of these indicators signalled a reduction of the number of treatments $(n=41,72 \%)$, namely in UK, US, and Canada. Five international surveys to physicians $[112,114,126,132,137]$ also reported that this type of cancer therapy was affected.

342 With respect to systemic anticancer therapy, 43 indicators were identified from 9 articles $343[42,53,55,72,96,106,111,139,140]$, concerning Italy, France, UK, Spain, and the US. The majority $344(\mathrm{n}=40,93 \%)$ showed a decrease in requests for initial treatment and in the number of chemotherapy administrations. Six surveys $[58,109,112,115,134,141]$ reported on this treatment modality. One study including 54 countries [46] showed that $88.2 \%$ of centers reported a reduction in their usual level of care, while $9.83 \%$ of those reported lack of access to medications. A European study with 29 countries [109] reported that $6 \%$ of centers revealed shortages of drugs. 
medRxiv preprint doi: $h t$ tps://doi.org/10.1101/2022.02.23.22271303; this version posted February 26, 2022. The copyright holder for this preprint (which was not certified by peer review) is the author/funder, who has granted medRxiv a license to display the preprint in

perpetuity.
It is made available under a CC-BY 4.0 International license .

349 A total of 28 indicators (from 3 articles) $[55,139,140]$ reported on systemic anticancer therapy after

350 lockdown ending (from May to October 2020). Of these indicators, $14(50 \%)$ reported an increase in

351 the number of treatments (in UK and France).

Regarding "delay in treatment", a total of 42 indicators from 18 articles $[39,52,72,77,81,89,91,92,96,97,99,101,138,142-146]$ were identified. Of those, 18 (43\%) reported an increasing trend in waiting time to treatment, namely in France, Portugal, Canada, US, and Italy. Sixteen indicators (38\%) signalled stable waiting times and $8(19 \%)$ a reduction in time to treatment. Twenty-one surveys $[58,70,84-86,88,108,109,114,117,132-134,141,147-153], 2$ studies using administrative data and surveys [121,138] and 1 prospective study [117] reported on delays in cancer treatment. From those, eleven articles were international studies. All have reported delays or interruptions on different aspects of cancer treatment, namely in Canada, France, Germany, Italy, Netherlands, US, and UK.

362 Fifty articles reported on "changes in treatment", resulting in 304 indicators collated. A total of 106 indicators (19 articles [50,52,65,75,77,90,96-98,101,102,106,118,121,135,137,138,142,154]) were collected from administrative data, 13 indicators from registry data [134,138] and 185 were surveybase information $[13,46,58,70,78,85,88,113-116,126,130,141,145,148-151,155-159]$. Changes in treatment are summarized in Fig. 3. 
medRxiv preprint doi: https://doi.org/10.1101/2022.02.23.22271303; this version posted February 26, 2022. The copyright holder for this preprint (which was not certified by peer review) is the author/funder, who has granted medRxiv a license to display the preprint in perpetuity.

It is made available under a CC-BY 4.0 International license.

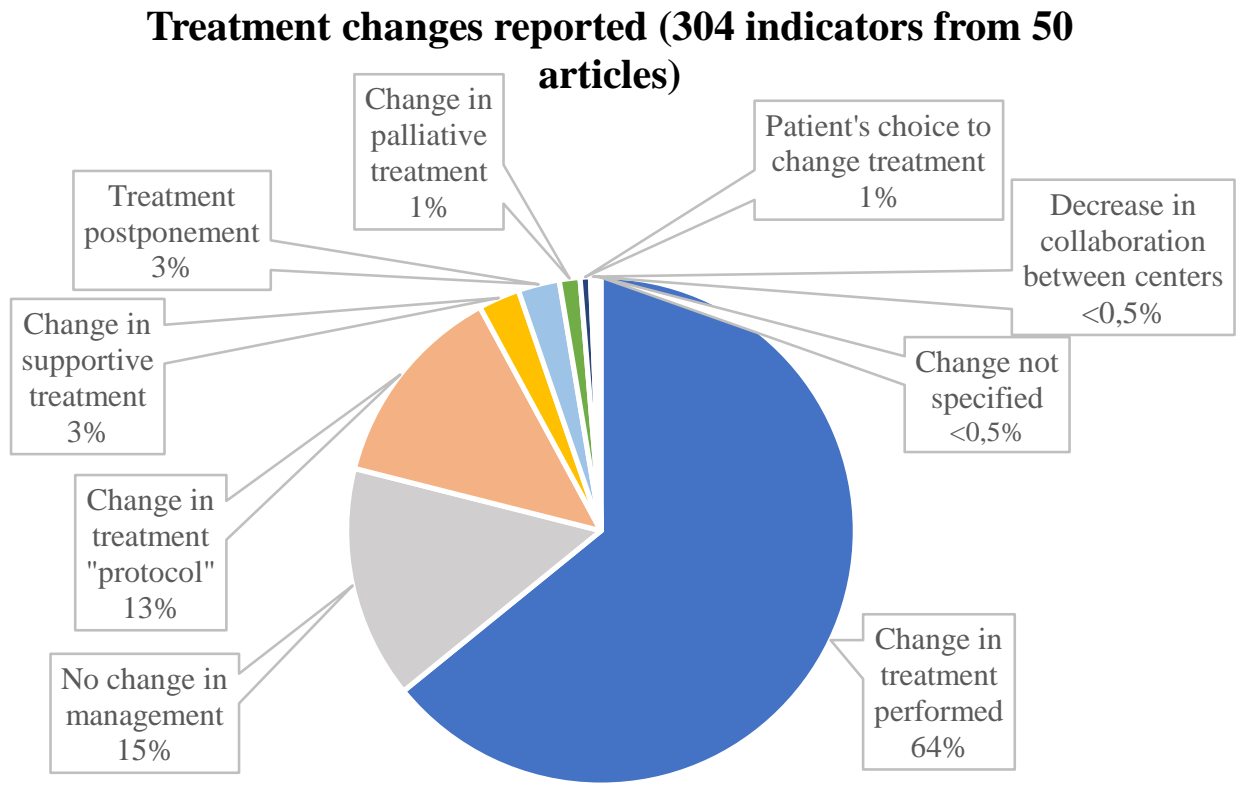

\section{Change in treatment performed ( $\mathrm{n}=195$ indicators)}

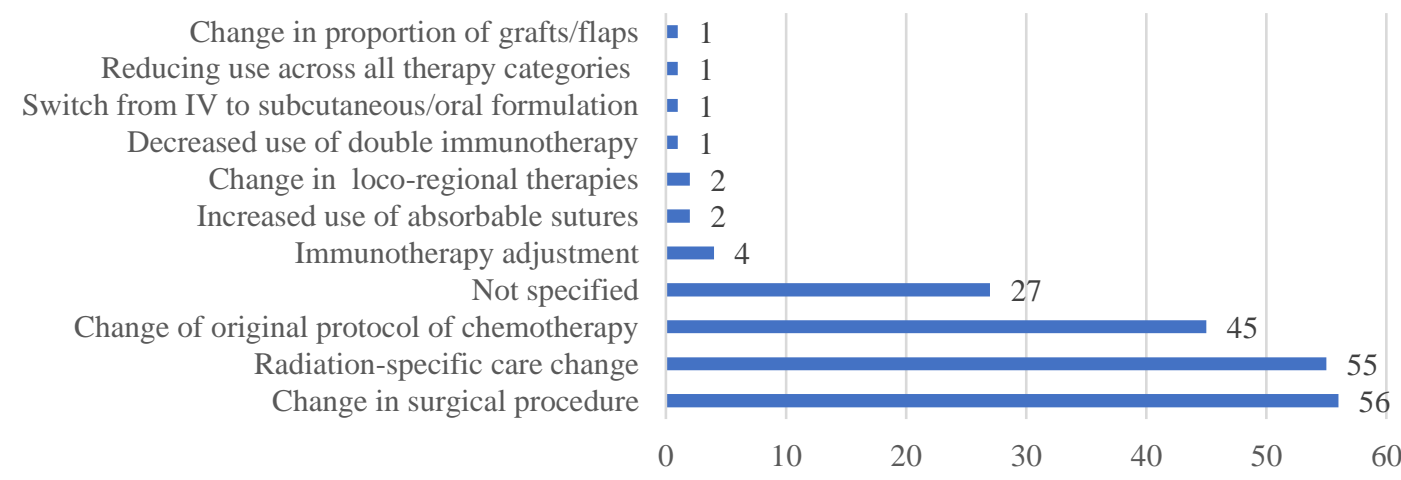

Change in treatment "protocol" $(n=40)$

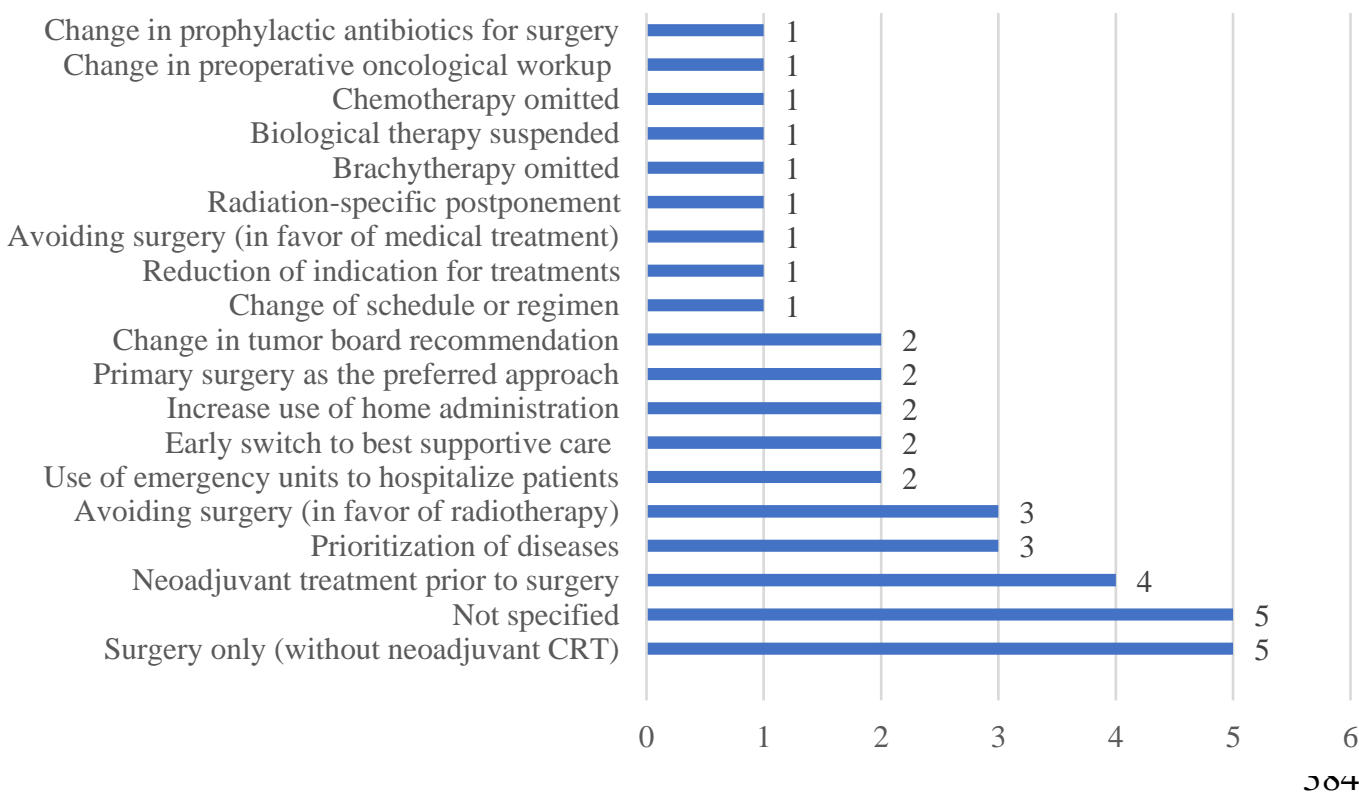

385 Fig. 3 - Treatment changes reported in the articles. IV: intravenous; CRT: chemotherapy. 
medRxiv preprint doi: https://doi.org/10.1101/2022.02.23.22271303; this version posted February 26,2022 . The copyright holder for this preprint (which was not certified by peer review) is the author/funder, who has granted medRxiv a license to display the preprint in

It is made available under a CC-BY 4.0 International license.

387 Modifications in treatment were reported in 195 (64\%) of indicators. The most frequent changes in 388 treatment were in surgical procedures $(\mathrm{n}=56$ indicators, 29\%), radiation-specific changes $(\mathrm{n}=55$ 389 indicators, 28\%) and change of original protocol of chemotherapy ( $\mathrm{n}=45$ indicators, 23\%).

390 Modifications documented in surgical procedures were a decrease in use of laparoscopic surgery 391 together with an increase of open or radical surgery, an increase in stoma formation rate, and a decrease of immediate breast reconstruction rate in breast cancer patients. The radiation-specific care variations 393 identified were radiotherapy hypofractionation, treatment disruptions, increase in short-course treatments, and physicians being less likely to prescribe adjuvant radiotherapy.

Treatment "protocol" changes were reported by 40 indicators. The most frequent change was performing surgery without neoadjuvant chemotherapy (Fig. 3).

A total of 12 indicators from 4 articles $[42,55,93,99]$ reported on the "number of visits and admissions" of cancer patients to the hospital. Of these indicators, $10(83 \%)$ signalled a decreasing trend. Two international surveys $[55,85]$ to health professionals have also disclosed a decrease in the number of oncology unit hospitalizations.

Regarding the "utilization of telemedicine", 4 indicators were identified from 4 articles [68,86,103,152]. Fourteen surveys [13,58,70,109,112-115,134,141,145,149,152,157] provided information on telemedicine use, from which ten were international studies. Three were patients' surveys. All the survey-based information and quantitative indicators reported an increase in the use of telehealth to provide cancer care. One article [160] assessed patient and providers' satisfaction regarding the use of telemedicine in rehabilitation of cancer patients. The proportion of patients that provided good feedback ranged from $63 \%$ to $84 \%$, and the physicians' perspective was also satisfactory, ranging from $66 \%$ to $83 \%$ of physicians reporting positive feedback. Four international surveys $[115,141,145,150]$ addressed the implementation of virtual multidisciplinary tumor boards, showing a marked increase in the use of web-based platforms. 
medRxiv preprint doi: https://doi.org/10.1101/2022.02.23.22271303; this version posted February 26, 2022. The copyright holder for this preprint (which was not certified by peer review) is the author/funder, who has granted medRxiv a license to display the preprint in It is made available under a CC-BY 4.0 International license.

412 Two main outcomes were addressed in the included articles: "procedures and surgical outcome 413 measures" and "mortality". Fifteen indicators from 8 articles [93,97-103] conveyed information 414 regarding procedures' outcomes. From these indicators, 11 (73\%) showed similar complication rates. 415 One Italian survey [127] has also documented a stable number of complications after esophageal 416 resections.

417 With respect to mortality in cancer patients, 24 indicators were identified from 4 articles. Twenty of 418 these indicators resulted from one Portuguese study [105], the other 3 indicators showed a stable 419 postoperative death rate in patients with head and neck cancer (France) [102], and a stable in-hospital 420 mortality rate for orthopedic tumors at the traumatology department (Germany) [123]. One Turkish 421 study [100] documented increased mortality in occlusive colorectal cancers patients.

422 The trends of the indicators are summarized in Fig. 4. 


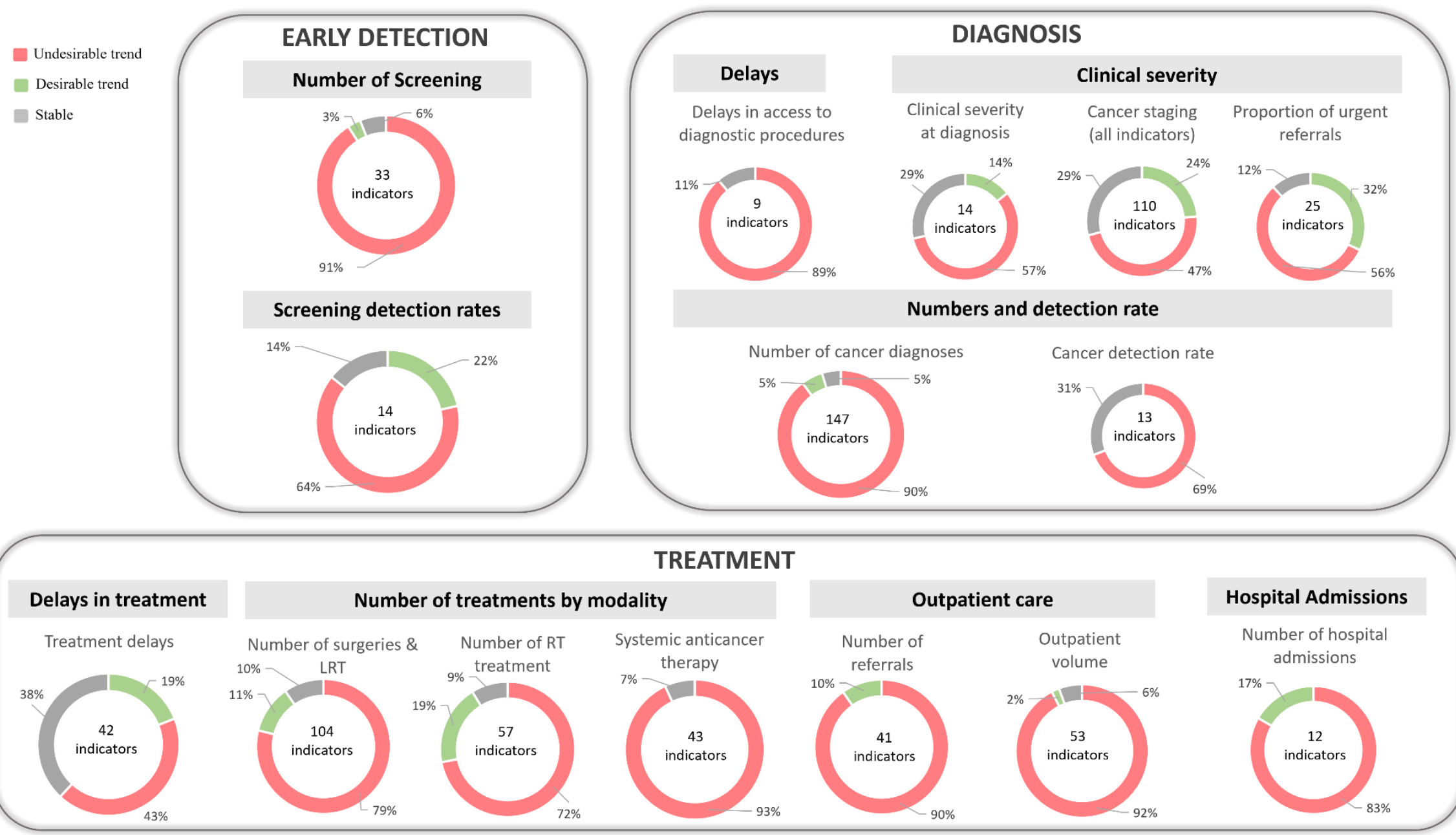

Fig. 4 - Number of cancer care indicators and trends per category (\%), according to the cancer care pathway 


\section{Discussion}

427 In this study, we performed a scoping review to identify the indicators used in the literature to measure 428 the impact of the COVID-19 pandemic on the cancer care pathway from January to June 2020, and the changes in the quality of care signalled by these indicators. We identified a total of 135 articles, with

430 a total of 917 quantitative indicators, reporting on 94 countries. Changes in the quality of care are 431 spread across the care pathway. This performance information suggests capacity constraints, it shows 432 quick adaptations and innovations in cancer management. If collected in near-real-time and processed into actionable information, it would allow monitoring changes in care during the current pandemic and in future events more efficiently, supporting timely and adequate responses.

435 Our findings signal a major impact on the diagnosis of cancer: a decreasing trend in the number of screenings, diagnostic procedures, and, consequently, in the number of cancer diagnoses, resulting in increasing screening detection rates, and delays in diagnostic care. These result from the reduction of screening programs [4], the cancelation of elective procedures [22], and patients' avoidance of going to healthcare facilities $[161,162]$. Previous studies documented the decreasing number of primary care consultations for a wide range of clinical conditions $[163,164]$ and a relevant fall in new cancer

441 diagnoses in primary care [76].

Trends regarding cancer staging at diagnosis portray a mixed picture. The reduction in the number of elective diagnostic procedures could explain stage-shifts in cancer presentation. We also found an increasing trend in the proportion of urgent/emergent cancer referrals and in the proportion of emergent procedures, as well as evidence of patients presenting with a more severe clinical condition to the

446 hospital than before the pandemic. These trends suggest patients with advanced-stage cancers 447 continued to seek care. It could also signal those patients waited longer before receiving care, with 448 potential deleterious outcomes. These results highlight the need to closely monitor the impact of the 449 COVID-19 pandemic on shifts in cancer staging at diagnosis and the relevance of collecting this data 
452 With respect to treatment, about $40 \%$ of the indicators reporting on waiting times to treatment signalled

453 an increasing trend, we observe a decreasing trend in the volume of the three modalities of cancer 454 treatment, and a large number and diversity of information reporting on treatment changes. These results reveal the remarkable influence of the pandemic on patterns of cancer care in the first half of 2020. These changes result from postponements of care decided by physicians to decrease patients' exposure to hospitals [113], switch to audio- or video-consultations, and deferrals and treatment modifications guided by updated recommendations by many medical societies [11,12]. Almost twothirds of the indicators reported changes in treatment, which shows that providers have quickly adapted their care practices, which strengthens the argument for the need for monitoring closely these changes. While some of these care modifications could be learning opportunities for the future, this information should be standardised, transparent, and timely, allowing to appraise the modifications in care provided during crises regarding access, quality, and outcomes.

The increase in telemedicine utilization we report is a generalized trend across a range of medical specialties [4] and it constitutes a hallmark of the innovation triggered by this pandemic. Albeit the positive feedback by physicians and patients we report, telehealth risks to increase inequalities in access to care $[166,167]$.

Short-term oncological outcomes were addressed by a few indicators and are reported as being stable, which is in line with a recent international cohort study including 61 countries and 15 tumor types [22]. However, deferred care will most likely lead to worse long-term outcomes, which needs to be monitored. Attempts to quantify this impact were developed, for instance, by a British nation-wide modelling study where the authors estimated a total of 59 204-63 229 additional years of life lost attributed to four major cancers [168], compared with pre-pandemic data.

Previous works addressed the impact of the COVID-19 pandemic on regional or national settings [5,50], on specific cancers [5,6,169], specific stages of the care pathway [54], or treatment modalities [22]. This scoping review provides a summary of cancer care performance indicators, concerning various diseases, from early detection to the treatment phase of the care pathway, within OECD countries. Additionally, we report changes in the quality of cancer care based on indicators' trends, 
medRxiv preprint doi: https://doi.org/10.1101/2022.02.23.22271303; this version posted February 26,2022 . The copyright holder for this preprint (which was not certified by peer review) is the author/funder, who has granted medRxiv a license to display the preprint in

It is made available under a CC-BY 4.0 International license.

479 from January to June 2020, which constitutes an innovative approach to assess changes in healthcare

480 performance.

481 Our study has some limitations. The heterogeneity of study designs, populations, diseases, indicators,

482 and indicators' definitions do not allow application of a meta-analysis approach and quantifying the

483 real impact of the pandemic on cancer care. We also recognize potential bias that could arise from the

484 inclusion of survey data, which rely on what respondents recall and report. However, a relevant number

485 of surveys were conducted by international societies and networks of providers, which allows for the

486 collection of credible information regarding changes in care. Surveys also show how medical societies

487 and countries were unable to obtain these data using current health information systems and data

488 structures. We acknowledge the patients' perspective is not comprehensive since only a few surveys

489 included patient-reported outcomes and experiences of care measures. The cancer care pathway is not

490 complete in this study, as it did not address primary prevention, rehabilitation, and palliative care.

491 Nonetheless, we provide a thorough overview of the cancer care pathway, from diagnosis to outcomes.

492 The distribution of studies per country is not homogenous in this study, which does not allow to

493 generalize these trends to all included countries or to fully assess disparities in cancer care between

494 OECD countries. Care inequalities could have been exacerbated during this pandemic, which needs to

495 be further studied regarding cancer care.

496 The COVID-19 pandemic keeps evolving until the present time and postponing of care was reported

497 in some countries by the end of 2021 and the beginning of 2022 [170,171], which means that this

498 impact is adding up. Figures concerning new COVID-19 cases, mortality, and vaccination coverage,

499 are presented daily to the public since the beginning of 2020. Additional and considerable efforts are

500 needed to expose the effects caused by this pandemic in non-COVID-19 care, and some of the

501 indicators we present could be useful to convey that message.

502 As new waves keep evolving, it is crucial to monitor performance indicators, such as shifts in cancer

503 staging or worsening of outcomes, closely and promptly. Also, the link between structure, process, and

504 (short- and long-term) outcome indicators should be undertaken to allow an accurate and timely 
medRxiv preprint doi: https://doi.org/10.1101/2022.02.23.22271303; this version posted February 26, 2022. The copyright holder for this preprint (which was not certified by peer review) is the author/funder, who has granted medRxiv a license to display the preprint in

perpetuity.
It is made available under a CC-BY 4.0 International license .

505 evaluation of the changes in the care provided during crises (and in regular times). Tools like the "Time

506 to Act Data Navigator" [172] developed by the European Cancer Organization and the "Global Cancer

507 Observatory" [173] signal the ambition to address this lack of standardised and regular collection of

508 data and indicators. Within the scope of Europe's Beating Cancer Plan, the European Cancer

509 Inequalities Registry [20] aims to monitor inequalities across Europe, by providing reliable data on

510 cancer prevention and care.

512 Conclusion

513 Our results provide a summary of performance indicators used in the literature to assess the cancer

514 care pathway from January 2020 to June 2020, and the changes in the quality of care signalled by these

515 indicators. This study shows that health systems struggled to ensure the continuity in the quality of

516 care to cancer patients in OECD countries. This information could inform on the bottlenecks of the

517 cancer care pathway and contribute to identifying disparities between and within countries, as well as

518 moments for intervention during the evolving pandemic and in future crises. Further research and

519 investment are necessary to generate system-wide oriented intelligence and strengthen data

520 infrastructures worldwide, to support timely and adequate health policy responses. 
medRxiv preprint doi: https://doi.org/10.1101/2022.02.23.22271303; this version posted February 26, 2022. The copyright holder for this preprint (which was not certified by peer review) is the author/funder, who has granted medRxiv a license to display the preprint in perpetuity.

It is made available under a CC-BY 4.0 International license.

\section{Acknowledgements}

523 The authors wish to thank Wichor Bramer from the Erasmus MC Medical Library for developing and

524 updating the search strategies used in this study.

526 Funding

527 This research received no specific grant from any funding agency in the public, commercial, or not-

528 for-profit sectors.

530 Conflict of interest

$531 \quad$ None declared.

533 Ethics approval and consent to participate

534 Not required.

\section{Data availability}

537 The data underlying this article are available in Zenodo.org, at

538 https://doi.org/10.5281/zenodo.6129839.

540 Authors' contributions

541 All authors contributed to conceptualize the study. ASC and MdL performed the data collection. ASC

542 performed the data analysis and drafted the article. All authors provided feedback and contributed to

543 revising the manuscript. All authors approved the final version of the manuscript. 


\section{References}

546 1. World Health Organization. A year without precedent: WHO's COVID-19 response [Internet].

547 [cited 2022 Feb 11]. Available from: https://www.who.int/news-room/spotlight/a-year-without-

548 precedent-who-s-covid-19-response

2. World Health Organization. Pulse survey on continuity of essential health services during the COVID-19 pandemic - Key informant findings from 135 countries, territories and areas - Quarter 1 2021 Reporting period: 3 months preceding date of survey submission [Internet]. [cited 2022 Jan 18]. Available from: https://www.who.int/docs/default-source/coronaviruse/finalupdate_22-april2021_summary-ppt_ehs-pulse-survey_second-round.pdf?sfvrsn=a965e121_8

3. World Health Organization. Health Topics - Cancer [Internet]. [cited 2022 Jan 25]. Available from: https://www.who.int/health-topics/cancer\#tab=tab_1

4. OECD. Health at a Glance 2021: OECD Indicators, OECD Publishing, Paris. [Internet]. 2021. Available from: https://doi.org/10.1787/ae3016b9-en.

5. Eijkelboom AH, de Munck L, Vrancken Peeters M-JTFD, Broeders MJM, Strobbe LJA, Bos MEMM, et al. Impact of the COVID-19 pandemic on diagnosis, stage, and initial treatment of breast cancer in the Netherlands: a population-based study. J Hematol OncolJ Hematol Oncol. 2021;14:64. Impact of COVID-19 and suspension of colorectal cancer screening on incidence and stage distribution of colorectal cancers in the Netherlands. Eur J Cancer. 2022;161:38-43. 
medRxiv preprint doi: https://doi.org/10.1101/2022.02.23.22271303; this version posted February 26, 2022. The copyright holder for this preprint (which was not certified by peer review) is the author/funder, who has granted medRxiv a license to display the preprint in It is made available under a CC-BY 4.0 International license.

567 8. Peacock HM, Tambuyzer T, Verdoodt F, Calay F, Poirel HA, De Schutter H, et al. Decline and 568 incomplete recovery in cancer diagnoses during the COVID-19 pandemic in Belgium: a year-long, 569 population-level analysis. ESMO Open. 2021;6:100197.

9. Skovlund CW, Friis S, Dehlendorff C, Nilbert MC, Mørch LS. Hidden morbidities: drop in cancer diagnoses during the COVID-19 pandemic in Denmark. Acta Oncol. 2021;60:20-3.

10. Burki TK. Cancer guidelines during the COVID-19 pandemic. Lancet Oncol. 2020;21:629-30. sustainability and recovery in the COVID 19 pandemic. [Internet]. [cited 2021 Dec 9]. Available from: ttps://baso.org.uk/media/99217/baso_guidance_for_cancer_surgery_9th_april_2020_v7.pdf patients during the COVID-19 pandemic: an ESMO multidisciplinary expert consensus. Ann Oncol. 2020;31:1320-35.

13. Chazan G, Franchini F, Alexander M, Banerjee S, Mileshkin L, Blinman P, et al. Impact of

580 COVID-19 on cancer service delivery: results from an international survey of oncology clinicians. ESMO Open. 2020;5:e001090. Goals. [Internet]. [cited 2022 Jan 11]. Available from: https://sdgs.un.org/goals context of an integrated approach. [Internet]. 2017 [cited 2022 Jan 11]. Available from: https://apps.who.int/iris/bitstream/handle/10665/275676/A70_R12-en.pdf?sequence=1\&isAllowed=y survival in five continents: a worldwide population-based study (CONCORD). Lancet Oncol. $2008 ; 9: 730-56$. 
medRxiv preprint doi: https://doi.org/10.1101/2022.02.23.22271303; this version posted February 26, 2022. The copyright holder for this preprint (which was not certified by peer review) is the author/funder, who has granted medRxiv a license to display the preprint in It is made available under a CC-BY 4.0 International license.

590 17. Allemani C, Weir HK, Carreira H, Harewood R, Spika D, Wang X-S, et al. Global surveillance of 591 cancer survival 1995-2009: analysis of individual data for 25676887 patients from 279 population592 based registries in 67 countries (CONCORD-2). The Lancet. 2015;385:977-1010.

593 18. European Comission. Public health - Non-communicable diseases - Cancer. [Internet]. [cited 2022 594 Jan 17]. Available from: https://ec.europa.eu/health/non-communicable-diseases/cancer_en

595 19. European Comission. Communication from the Commission to the European Parliament and the 596 Council - Europe's Beating Cancer Plan. [Internet]. 2021 [cited 2022 Jan 11]. Available from: 597 https://ec.europa.eu/health/sites/default/files/non_communicable_diseases/docs/eu_cancer598 plan_en.pdf

599 20. European Comission. European Cancer Inequalities Registry. [Internet]. [cited 2022 Jan 24]. 600 Available from: https://cancer-inequalities.jrc.ec.europa.eu/

601 21. European Comission. EU Science Hub. Launch of the EC Knowledge Centre on Cancer. [Internet]. 602 [cited 2022 Jan 11]. Available from: https://ec.europa.eu/jrc/en/event/conference/launch-ec603 knowledge-centre-cancer 22. Glasbey J, Ademuyiwa A, Adisa A, AlAmeer E, Arnaud AP, Ayasra F, et al. Effect of COVID-19 605 pandemic lockdowns on planned cancer surgery for 15 tumour types in 61 countries: an international, 606 prospective, cohort study. Lancet Oncol. 2021;22:1507-17.

607 23. Blay JY, Boucher S, Le Vu B, Cropet C, Chabaud S, Perol D, et al. Delayed care for patients with 608 newly diagnosed cancer due to COVID-19 and estimated impact on cancer mortality in France. ESMO 609 Open. 2021;6:100134.

610 24. Kirchberg J, Rentsch A, Klimova A, Vovk V, Hempel S, Folprecht G, et al. Influence of the First 611 Wave of the COVID-19 Pandemic on Cancer Care in a German Comprehensive Cancer Center. Front 612 Public Health. 2021;9:750479. 
medRxiv preprint doi: https://doi.org/10.1101/2022.02.23.22271303; this version posted February 26, 2022. The copyright holder for this preprint (which was not certified by peer review) is the author/funder, who has granted medRxiv a license to display the preprint in

perpetuity.
It is made available under a CC-BY 4.0 International license .

613 25. Kringos D, Carinci F, Barbazza E, Bos V, Gilmore K, Groene O, et al. Managing COVID-19

614 within and across health systems: why we need performance intelligence to coordinate a global

615 response. Health Res Policy Syst. 2020;18:80.

616 26. Arksey H, O’Malley L. Scoping studies: towards a methodological framework. Int J Soc Res

617 Methodol. 2005;8:19-32.

27. Levac D, Colquhoun H, O’Brien KK. Scoping studies: advancing the methodology. Implement

619 Sci. 2010;5:69.

28. Tolonen H, Reinikainen J, Koponen P, Elonheimo H, Palmieri L, Tijhuis MJ, et al. Cross-national comparisons of health indicators require standardized definitions and common data sources. Arch Public Health. 2021;79:208.

29. Lockwood C, dos Santos KB, Pap R. Practical Guidance for Knowledge Synthesis: Scoping Review Methods. Asian Nurs Res. 2019;13:287-94.

30. Munn Z, Peters MDJ, Stern C, Tufanaru C, McArthur A, Aromataris E. Systematic review or scoping review? Guidance for authors when choosing between a systematic or scoping review approach. BMC Med Res Methodol. 2018;18:143. Scoping Reviews (PRISMA-ScR): Checklist and Explanation. Ann Intern Med. 2018;169:467-73. systematic reviews. Syst Rev. 2016;5:210. diagnostics referral center during the COVID-19 pandemic. Mol Biol Rep. 2020;47:4857-60. delay during the COVID-19 pandemic: How to act? Mol Biol Rep. 2021;48:983-7. 
medRxiv preprint doi: https://doi.org/10.1101/2022.02.23.22271303; this version posted February 26,2022 . The copyright holder for this preprint (which was not certified by peer review) is the author/funder, who has granted medRxiv a license to display the preprint in perpetuity.

It is made available under a CC-BY 4.0 International license.

636 35. London JW, Fazio-Eynullayeva E, Palchuk MB, Sankey P, McNair C. Effects of the COVID-19

637 Pandemic on Cancer-Related Patient Encounters. JCO Clin Cancer Inform. 2020;657-65.

638 36. Henderson LM, Benefield T, Bosemani T, Long JM, Rivera MP. Impact of the COVID-19

639 Pandemic on Volumes and Disparities in Lung Cancer Screening. Chest. 2021;160:379-82.

640 37. Bakouny Z, Paciotti M, Schmidt AL, Lipsitz SR, Choueiri TK, Trinh Q-D. Cancer Screening Tests 641 and Cancer Diagnoses During the COVID-19 Pandemic. JAMA Oncol. 2021;7:458.

642 38. Miller MJ, Xu L, Qin J, Hahn EE, Ngo-Metzger Q, Mittman B, et al. Impact of COVID-19 on 643 Cervical Cancer Screening Rates Among Women Aged 21-65 Years in a Large Integrated Health Care 644 System - Southern California, January 1-September 30, 2019, and January 1-September 30, 2020. 645 MMWR Morb Mortal Wkly Rep. 2021;70:109-13.

39. Suárez J, Mata E, Guerra A, Jiménez G, Montes M, Arias F, et al. Impact of the COVID-19 647 pandemic during Spain's state of emergency on the diagnosis of colorectal cancer. J Surg Oncol. 2021;123:32-6.

40. Maganty A, Yu M, Anyaeche VI, Zhu T, Hay JM, Davies BJ, et al. Referral pattern for urologic malignancies before and during the COVID-19 pandemic. Urol Oncol Semin Orig Investig. 2021;39:268-76.

41. Toss A, Isca C, Venturelli M, Nasso C, Ficarra G, Bellelli V, et al. Two-month stop in mammographic screening significantly impacts on breast cancer stage at diagnosis and upfront treatment in the COVID era. ESMO Open. 2021;6:100055.

42. Patt D, Gordan L, Diaz M, Okon T, Grady L, Harmison M, et al. Impact of COVID-19 on Cancer 656 Care: How the Pandemic Is Delaying Cancer Diagnosis and Treatment for American Seniors. JCO 657 Clin Cancer Inform. 2020;1059-71. care: Mammograms during the COVID-19 pandemic. Health Serv Res. 2021;56:95-101. 
medRxiv preprint doi: https://doi.org/10.1101/2022.02.23.22271303; this version posted February 26, 2022. The copyright holder for this preprint (which was not certified by peer review) is the author/funder, who has granted medRxiv a license to display the preprint in It is made available under a CC-BY 4.0 International license.

660 44. Yin K, Singh P, Drohan B, Hughes KS. Breast imaging, breast surgery, and cancer genetics in the 661 age of COVID-19. Cancer. 2020;126:4466-72.

662 45. Nyante, S. J., Benefield, T. S., Kuzmiak, C. M., Earnhardt, K., Pritchard, M., Henderson, L. M. 663 Population-level impact of coronavirus disease 2019 on breast cancer screening and diagnostic 664 procedures. Cancer. 2021;127:2111-21.

46. Rocco N, Montagna G, Di Micco R, Benson J, Criscitiello C, Chen L, et al. The Impact of the COVID-19 Pandemic on Surgical Management of Breast Cancer: Global Trends and Future 667 Perspectives. The Oncologist. 2021;26:e66-77.

47. D’Ovidio V, Lucidi C, Bruno G, Lisi D, Miglioresi L, Bazuro ME. Impact of COVID-19 Pandemic on Colorectal Cancer Screening Program. Clin Colorectal Cancer. 2021;20:e5-11.

48. Furnari M, Eusebi LH, Savarino E, Petruzzellis C, Esposito G, Maida M, et al. Effects of SARSCoV-2 emergency measures on high-risk lesions detection: a multicentre cross-sectional study. Gut. $2021 ; 70: 1241-3$. pandemic on elective urological procedures in Australia. Asian J Urol. 2022;9:35-41. Eur J Cancer. 2020;138:S116.

51. O’Connor E, O’Dowd G, Phelan S. Impact of COVID-19 on small biopsy diagnostic procedures and cancer resection surgeries in the North-West of Ireland. J Clin Pathol. 2021;jclinpath-2021207425. 19 on the management of hepatocellular carcinoma in a high-prevalence area. JHEP Rep. 2021;3:100199. 
medRxiv preprint doi: https://doi.org/10.1101/2022.02.23.22271303; this version posted February 26, 2022. The copyright holder for this preprint (which was not certified by peer review) is the author/funder, who has granted medRxiv a license to display the preprint in It is made available under a CC-BY 4.0 International license.

684 COVID-19 Outbreak on Cancer Patient Care and Treatment: Data from an Outpatient Oncology Clinic 685 in Lombardy (Italy). Cancers. 2020;12:2941.

54. Lantinga MA, Theunissen F, ter Borg PCJ, Bruno MJ, Ouwendijk RJT, Siersema PD, et al. Impact of the COVID-19 pandemic on gastrointestinal endoscopy in the Netherlands: analysis of a prospective endoscopy database. Endoscopy. 2021;53:166-70. COVID-19 national containment on activities in the French northern comprehensive cancer center. Med Oncol. 2021;38:28.

56. Markar SR, Clarke J, Kinross J. Practice patterns of diagnostic upper gastrointestinal endoscopy during the initial COVID-19 outbreak in England. Lancet Gastroenterol Hepatol. 2020;5:804-5. disease 2019 on surveillance colonoscopies in South Australia. JGH Open. 2021;5:486-92. service provision. Br J Surg. 2020;107:e521-2. endoscopic activity and cancer detection: a National Endoscopy Database Analysis. Gut. $2021 ; 70: 537-43$. diagnosis and management in Slovenia - preliminary results. Radiol Oncol. 2020;54:329-34. COVID-19 epidemic according to diagnosis, age and region. TSG - Tijdschr Voor Gezondheidswetenschappen. 2021;99:1-8. 
medRxiv preprint doi: https://doi.org/10.1101/2022.02.23.22271303; this version posted February 26, 2022. The copyright holder for this preprint (which was not certified by peer review) is the author/funder, who has granted medRxiv a license to display the preprint in

perpetuity.
It is made available under a CC-BY 4.0 International license .

706 62. Barruscotti S, Giorgini C, Brazzelli V, Vassallo C, Michelerio A, Klersy C, et al. A significant

707 reduction in the diagnosis of melanoma during the COVID-19 lockdown in a third-level center in the

708 Northern Italy. Dermatol Ther [Internet]. 2020 [cited 2022 Feb 17];33. Available from:

709 https://onlinelibrary.wiley.com/doi/10.1111/dth.14074

710 63. Ferrara G, De Vincentiis L, Ambrosini-Spaltro A, Barbareschi M, Bertolini V, Contato E, et al.

711 Cancer Diagnostic Delay in Northern and Central Italy During the 2020 Lockdown Due to the

712 Coronavirus Disease 2019 Pandemic. Am J Clin Pathol. 2021;155:64-8.

713 64. Kaufman HW, Chen Z, Niles J, Fesko Y. Changes in the Number of US Patients With Newly

714 Identified Cancer Before and During the Coronavirus Disease 2019 (COVID-19) Pandemic. JAMA

715 Netw Open. 2020;3:e2017267.

716 65. Kiong KL, Guo T, Yao CMKL, Gross ND, Hanasono MM, Ferrarotto R, et al. Changing practice 717 patterns in head and neck oncologic surgery in the early COVID -19 era. Head Neck. 2020;42:1179$718 \quad 86$

719 66. Vigliar E, Cepurnaite R, Alcaraz-Mateos E, Ali SZ, Baloch ZW, Bellevicine C, et al. Global impact 720 of the COVID-19 pandemic on cytopathology practice: Results from an international survey of 721 laboratories in 23 countries. Cancer Cytopathol. 2020;128:885-94.

67. Ricci F, Fania L, Paradisi A, Di Lella G, Pallotta S, Sobrino L, et al. Delayed melanoma diagnosis in the COVID-19 era: increased breslow thickness in primary melanomas seen after the COVID-19 lockdown. J Eur Acad Dermatol Venereol [Internet]. 2020 [cited 2022 Feb 17];34. Available from: https://onlinelibrary.wiley.com/doi/10.1111/jdv.16874 Secondary Care Centre During the Coronavirus Disease 2019 Pandemic. Am J Dermatopathol. 2021;43:160-2. 
medRxiv preprint doi: https://doi.org/10.1101/2022.02.23.22271303; this version posted February 26, 2022. The copyright holder for this preprint (which was not certified by peer review) is the author/funder, who has granted medRxiv a license to display the preprint in It is made available under a CC-BY 4.0 International license. Disease 2019 (COVID-19) Pandemic. Obstet Gynecol. 2020;136:842-3.

731 70. Panzuto F, Maccauro M, Campana D, Faggiano A, Massironi S, Pusceddu S, et al. Impact of the SARS-CoV2 pandemic dissemination on the management of neuroendocrine neoplasia in Italy: a report from the Italian Association for Neuroendocrine Tumors (Itanet). J Endocrinol Invest. $734 \quad 2021 ; 44: 989-94$. en el diagnóstico precoz del melanoma. Med Clínica. 2021;156:356-7.

72. Gathani T, Clayton G, MacInnes E, Horgan K. The COVID-19 pandemic and impact on breast cancer diagnoses: what happened in England in the first half of 2020. Br J Cancer. 2021;124:710-2. COVID-19 pandemic on the presentation status of newly diagnosed melanoma: A single institution experience. J Am Acad Dermatol. 2021;84:1096-8.

74. Dinmohamed AG, Cellamare M, Visser O, de Munck L, Elferink MAG, Westenend PJ, et al. The impact of the temporary suspension of national cancer screening programmes due to the COVID-19 epidemic on the diagnosis of breast and colorectal cancer in the Netherlands. J Hematol OncolJ Hematol Oncol. 2020;13:147.

75. Wang H, Elsheikh M, Gilmour K, Cohen V, Sagoo MS, Damato B, et al. Impact of COVID-19 pandemic on eye cancer care in United Kingdom. Br J Cancer. 2021;124:1357-60. 2021;13:408. 
medRxiv preprint doi: https://doi.org/10.1101/2022.02.23.22271303; this version posted February 26, 2022. The copyright holder for this preprint (which was not certified by peer review) is the author/funder, who has granted medRxiv a license to display the preprint in It is made available under a CC-BY 4.0 International license.

751 77. Van Haren RM, Delman AM, Turner KM, Waits B, Hemingway M, Shah SA, et al. Impact of the 752 COVID-19 Pandemic on Lung Cancer Screening Program and Subsequent Lung Cancer. J Am Coll 753 Surg. 2021;232:600-5.

78. Price SJ, Joannides A, Plaha P, Afshari FT, Albanese E, Barua NU, et al. Impact of COVID-19 pandemic on surgical neuro-oncology multi-disciplinary team decision making: a national survey (COVID-CNSMDT Study). BMJ Open. 2020;10:e040898.

79. Dinmohamed AG, Visser O, Verhoeven RHA, Louwman MWJ, van Nederveen FH, Willems SM, et al. Fewer cancer diagnoses during the COVID-19 epidemic in the Netherlands. Lancet Oncol. 2020;21:750-1.

80. Valenti M, Pavia G, Gargiulo L, Facheris P, Nucca O, Mancini L, et al. Impact of delay in followup due to COVID-19 pandemic on skin cancer progression: a real-life experience from an Italian hub hospital. Int J Dermatol. 2021;60:860-3.

81. Kiong KL, Diaz EM, Gross ND, Diaz EM, Hanna EY. The impact of COVID-19 on head and neck cancer diagnosis and disease extent. Head Neck. 2021;43:1890-7.

82. Marson JW, Maner BS, Harding TP, Meisenheimer J, Solomon JA, Leavitt M, et al. The magnitude of COVID-19's effect on the timely management of melanoma and nonmelanoma skin cancers. J Am Acad Dermatol. 2021;84:1100-3. Pandemic effect on Cytopathology Practice: Results from 23 Laboratories in 11 Countries. J Am Soc Cytopathol. 2020;9:S51. Surg. 2020;272:e112-7. 
medRxiv preprint doi: https://doi.org/10.1101/2022.02.23.22271303; this version posted February 26, 2022. The copyright holder for this preprint (which was not certified by peer review) is the author/funder, who has granted medRxiv a license to display the preprint in It is made available under a CC-BY 4.0 International license .

85. Santoro GA, Grossi U, Murad-Regadas S, Nunoo-Mensah JW, Mellgren A, Di Tanna GL, et al. DElayed COloRectal cancer care during COVID-19 Pandemic (DECOR-19): Global perspective from an international survey. Surgery. 2021;169:796-807.

86. Papautsky EL, Hamlish T. Patient-reported treatment delays in breast cancer care during the COVID-19 pandemic. Breast Cancer Res Treat. 2020;184:249-54. Impact of COVID-19 on Handling NET Patients. J Clin Med. 2020;9:3633.

88. Boyle JM, Kuryba A, Blake HA, Aggarwal A, Meulen J, Walker K, et al. The impact of the first peak of the COVID-19 pandemic on colorectal cancer services in England and Wales: A national survey. Colorectal Dis. 2021;23:1733-44.

89. Andrew TW, Alrawi M, Lovat P. Reduction in skin cancer diagnoses in the UK during the COVID19 pandemic. Clin Exp Dermatol. 2021;46:145-6.

90. Nolan, G. S., Dunne, J. A., Kiely, A. L., Pritchard Jones, R. O., Gardiner, M, Jain, A. The effect of the COVID-19 pandemic on skin cancer surgery in the United Kingdom: a national, multi-centre, prospective cohort study and survey of Plastic Surgeons. J Br Surg. 2020;107:e598-600.

91. Taylor R, Omakobia E, Sood S, Glore RJ. The impact of coronavirus disease 2019 on head and neck cancer services: a UK tertiary centre study. J Laryngol Otol. 2020;134:684-7. pandemic on the detection and management of colorectal cancer in England: a population-based study. Lancet Gastroenterol Hepatol. 2021;6:199-208.

93. Kvolik Pavić A, Zubčić V, Kvolik S. Workload changes during the COVID-19 pandemic and effects on the flow of cancer patients in the Maxillofacial Surgery Department. Med Glas Ljek Komore Zenicko-Doboj Kantona [Internet]. 2021 [cited 2022 Feb 17]; Available from: https://doi.org/10.17392/1308-21 
medRxiv preprint doi: https://doi.org/10.1101/2022.02.23.22271303; this version posted February 26, 2022. The copyright holder for this preprint (which was not certified by peer review) is the author/funder, who has granted medRxiv a license to display the preprint in It is made available under a CC-BY 4.0 International license .

94. Vissio E, Falco EC, Collemi G, Borella F, Papotti M, Scarmozzino A, et al. Impact of COVID-19 lockdown measures on oncological surgical activity: Analysis of the surgical pathology caseload of a tertiary referral hospital in Northwestern Italy. J Surg Oncol. 2021;123:24-31.

95. Weston GK, Jeong HS, Mu EW, Polsky D, Meehan SA. Impact of COVID-19 on melanoma diagnosis. Melanoma Res. 2021;31:280-1.

96. Gosset M, Gal J, Schiappa R, Dejode M, Fouché Y, Alazet F, et al. Impact de la pandémie de COVID-19 sur les prises en charge pour cancer du sein et gynécologique. Bull Cancer (Paris). 2021;108:3-11.

97. Veiga J, Amante S, Costa NV, Luz JH, Gomes FV, Coimbra É, et al. The Covid-19 Pandemic Constraints May Lead to Disease Progression for Patients with Liver Cancer Scheduled to Receive Locoregional Therapies: Single-Centre Retrospective Analysis in an Interventional Radiology Unit. Cardiovasc Intervent Radiol. 2021;44:669-72.

98. Leung E, Pervaiz Z, Lowe-Zinola J, Cree S, Kwong A, Marriott N, et al. Maintaining surgical care delivery during the COVID-19 pandemic: A comparative cohort study at a tertiary gynecological cancer centre. Gynecol Oncol. 2021;160:649-54.

99. Rodrigues-Pinto E, Ferreira-Silva J, Fugazza A, Capogreco A, Repici A, Everett S, et al. Upper gastrointestinal stenting during the SARS-CoV-2 outbreak: impact of mitigation measures and risk of contamination for patients and staff. Endosc Int Open. 2021;09:E76-86.

100. Ferahman S, Dönmez T, Sürek A, Aydın H, Gümüşoğlu AY, Karabulut M. Effects of COVID19 Outbreak on Emergency Surgeries for Occlusive Colorectal Cancers. Turk J Colorectal Dis. 2020;30:237-45.

101. Vanni G, Tazzioli G, Pellicciaro M, Materazzo M, Paolo O, Cattadori F, et al. Delay in Breast Cancer Treatments During the First COVID-19 Lockdown. A Multicentric Analysis of 432 Patients. Anticancer Res. 2020;40:7119-25. 
medRxiv preprint doi: https://doi.org/10.1101/2022.02.23.22271303; this version posted February 26, 2022. The copyright holder for this preprint (which was not certified by peer review) is the author/funder, who has granted medRxiv a license to display the preprint in It is made available under a CC-BY 4.0 International license .

822 102. Laccourreye O, Mirghani H, Evrard D, Bonnefont P, Brugel L, Tankere F, et al. Impact of the

823 first month of Covid-19 lockdown on oncologic surgical activity in the Ile de France region university

824 hospital otorhinolaryngology departments. Eur Ann Otorhinolaryngol Head Neck Dis. 2020;137:2738256.

826 103. Filipe MD, van Deukeren D, Kip M, Doeksen A, Pronk A, Verheijen PM, et al. Effect of the 827 COVID-19 Pandemic on Surgical Breast Cancer Care in the Netherlands: A Multicenter Retrospective 828 Cohort Study. Clin Breast Cancer. 2020;20:454-61.

829 104. Purushotham A, Roberts G, Haire K, Dodkins J, Harvey-Jones E, Han L, et al. The impact of 830 national non-pharmaceutical interventions ('lockdowns') on the presentation of cancer patients. 831 ecancermedicalscience [Internet]. 2021 [cited 2022 Feb 17];15. Available from: 832 https://ecancer.org/en/journal/article/1180-the-impact-of-national-non-pharmaceutical-interventions833 lockdowns-on-the-presentation-of-cancer-patients

834 105. Morais S, Antunes L, Rodrigues J, Fontes F, Bento MJ, Lunet N. The impact of the COVID-19 835 pandemic on the short-term survival of patients with cancer in Northern Portugal. Int J Cancer. $836 \quad 2021 ; 149: 287-96$.

837 106. Manso L, De Velasco G, Paz-Ares L. Impact of the COVID-19 outbreak on cancer patient flow 838 and management: experience from a large university hospital in Spain. ESMO Open. 2020;5:e000828.

839 107. Rogado J, Obispo B, Gullón P, Lara MÁ. Impact of the COVID-19 pandemic in cancer diagnosis 840 in the first and second waves in one of the most affected cancer areas in the city of Madrid (Spain). Int $841 \quad J$ Cancer. 2021;148:1794-5.

842 108. Oderda M, Calleris G, Falcone M, Fasolis G, Muto G, Oderda G, et al. How uro-oncology has 843 been affected by COVID-19 emergency? Data from Piedmont/Valle d'Aosta Oncological Network, 844 Italy. Urol J. 2021;88:3-8. 
medRxiv preprint doi: https://doi.org/10.1101/2022.02.23.22271303; this version posted February 26,2022 . The copyright holder for this preprint (which was not certified by peer review) is the author/funder, who has granted medRxiv a license to display the preprint in It is made available under a CC-BY 4.0 International license.

109. Slotman BJ, Lievens Y, Poortmans P, Cremades V, Eichler T, Wakefield DV, et al. Effect of

846 COVID-19 pandemic on practice in European radiation oncology centers. Radiother Oncol. $847 \quad 2020 ; 150: 40-2$.

110. Park JY, Lee YJ, Kim T, Lee CY, Kim HI, Kim J-H, et al. Collateral effects of the coronavirus disease 2019 pandemic on lung cancer diagnosis in Korea. BMC Cancer. 2020;20:1040.

111. Zuliani S, Zampiva I, Tregnago D, Casali M, Cavaliere A, Fumagalli A, et al. Organisational challenges, volumes of oncological activity and patients' perception during the severe acute respiratory syndrome coronavirus 2 epidemic. Eur J Cancer. 2020;135:159-69.

112. Gordan, L. N., Weidner, S. Impact of the COVID-19 pandemic on specialty community practices: an oncology perspective. Am J Manag Care. 2020;26:SP333-5.

113. Gill S, Hao D, Hirte H, Campbell A, Colwell B. Impact of COVID-19 on Canadian Medical Oncol. 2020;27:71-4.

114. de Joode K, Dumoulin DW, Engelen V, Bloemendal HJ, Verheij M, van Laarhoven HWM, et al. Impact of the coronavirus disease 2019 pandemic on cancer treatment: the patients' perspective. Eur J Cancer. 2020;136:132-9. Medium- and Long-Term Impact of the COVID-19 Outbreak in Oncology. JCO Glob Oncol. $2021 ; 162-72$.

116. Nicholson P, Ali FR, Mallipeddi R. Impact of COVID-19 on Mohs micrographic surgery: UKwide survey and recommendations for practice. Clin Exp Dermatol. 2020;45:901-2. during the COVID-19 Pandemic. Respiration. 2021;100:90-2. 
medRxiv preprint doi: https://doi.org/10.1101/2022.02.23.22271303; this version posted February 26,2022 . The copyright holder for this preprint (which was not certified by peer review) is the author/funder, who has granted medRxiv a license to display the preprint in

perpetuity.
It is made available under a CC-BY 4.0 International license .

869 118. Lamblin G, Golfier F, Peron J, Moret S, Chene G, Nohuz E, et al. Impact de la pandémie de

870 Covid-19 sur les modifications thérapeutiques des patientes atteintes de cancers gynécologiques.

871 Gynécologie Obstétrique Fertil Sénologie. 2020;48:777-83.

872 119. Medas F, Ansaldo GL, Avenia N, Basili G, Bononi M, Bove A, et al. Impact of the COVID-19

873 pandemic on surgery for thyroid cancer in Italy: nationwide retrospective study. $\mathrm{Br} \mathrm{J}$ Surg.

$874 \quad 2021 ; 108: \mathrm{e} 166-7$.

120. Tejedor P, Simó V, Arredondo J, López-Rojo I, Baixauli J, Jiménez LM, et al. The impact of SARS-CoV-2 infection on the surgical management of colorectal cancer: Lessons learned from a multicenter study in Spain. Rev Esp Enfermedades Dig [Internet]. 2020 [cited 2022 Feb 17];113.

Available from: https://online.reed.es/fichaArticulo.aspx?iarf=687768749234-416277197164

121. Teckie S, Andrews JZ, Chen WC-Y, Goenka A, Koffler D, Adair N, et al. Impact of the COVID19 Pandemic Surge on Radiation Treatment: Report From a Multicenter New York Area Institution. JCO Oncol Pract. 2021;17:e1270-7.

122. Chang EI, Liu JJ. Flattening the curve in oncologic surgery: Impact of Covid-19 on surgery at tertiary care cancer center. J Surg Oncol. 2020;122:602-7.

123. Bolenz C, Vogel T, Morakis P, Mayr R, Marx M, Burger M. Uroonkologische Therapie in der ersten Welle der COVID-19-Pandemie: Was sagen uns die Krebsregister der deutschen Bundesländer? Urol. 2021;60:291-300.

124. Maluchnik M, Podwójcic K, Więckowska B. Decreasing access to cancer diagnosis and treatment during the COVID-19 pandemic in Poland. Acta Oncol. 2021;60:28-31. and Orthopedic Oncology. Healthcare. 2020;9:3. 
medRxiv preprint doi: https://doi.org/10.1101/2022.02.23.22271303; this version posted February 26,2022 . The copyright holder for this preprint (which was not certified by peer review) is the author/funder, who has granted medRxiv a license to display the preprint in It is made available under a CC-BY 4.0 International license .

892 126. Oba A, Stoop TF, Löhr M, Hackert T, Zyromski N, Nealon WH, et al. Global Survey on

893 Pancreatic Surgery During the COVID-19 Pandemic. Ann Surg. 2020;272:e87-93.

894 127. Rebecchi F, Arolfo S, Ugliono E, Morino M, Asti E, Bonavina L, et al. Impact of COVID-19 895 outbreak on esophageal cancer surgery in Northern Italy: lessons learned from a multicentric snapshot. 896 Dis Esophagus. 2021;34:doaa124.

897 128. PelvEx Collaborative, Chok AY, Kontovounisios C, Rasheed S, Kelly ME, Agj A, et al. The 898 impact of the COVID-19 pandemic on the Management of Locally Advanced Primary/Recurrent 899 Rectal Cancer. Br J Surg. 2020;107:e547-8.

900 129. Maccagnano C, Rocchini L, Montanari E, Conti GN, Petralia G, Dehò F, et al. Overview of the 901 italian experience in surgical management of bladder cancer during first month of COVID-19 902 pandemic. Arch Ital Urol E Androl [Internet]. 2020 [cited 2022 Feb 17];92. Available from: 903 https://www.pagepressjournals.org/index.php/aiua/article/view/aiua.2020.4.275

904 130. de la Portilla de Juan F, Reyes Díaz ML, Ramallo Solía I. Impact of the pandemic on surgical 905 activity in colorectal cancer in Spain. Results of a national survey. Cir Esp Engl Ed. 2021;99:500-5.

906 131. Brunner M, Krautz C, Kersting S, Weber GF, Stinner B, Benz SR, et al. Oncological colorectal 907 surgery during the COVID-19pandemic — a national survey. Int J Colorectal Dis. 2020;35:2219-25.

908 132. Gasparri ML, Gentilini OD, Lueftner D, Kuehn T, Kaidar-Person O, Poortmans P. Changes in 909 breast cancer management during the Corona Virus Disease 19 pandemic: An international survey of 910 the European Breast Cancer Research Association of Surgical Trialists (EUBREAST). The Breast. $911 \quad 2020 ; 52: 110-5$.

912 133. The Italian Colorectal Anastomotic Leakage (iCral) study group, Caricato M, Baiocchi GL, Crafa 913 F, Scabini S, Brisinda G, et al. Colorectal surgery in Italy during the Covid19 outbreak: a survey from 914 the iCral study group. Updat Surg. 2020;72:249-57. 
medRxiv preprint doi: https://doi.org/10.1101/2022.02.23.22271303; this version posted February 26, 2022. The copyright holder for this preprint (which was not certified by peer review) is the author/funder, who has granted medRxiv a license to display the preprint in It is made available under a CC-BY 4.0 International license.

915 134. Thaler M, Khosravi I, Leithner A, Papagelopoulos PJ, Ruggieri P. Impact of the COVID-19

916 pandemic on patients suffering from musculoskeletal tumours. Int Orthop. 2020;44:1503-9.

917 135. Higgins E, Walters S, Powell E, Staffurth J. The Impact of the Acute Phase of COVID-19 on 918 Radiotherapy Demand in South East Wales. Clin Oncol. 2020;32:e217.

919 136. Spencer K, Jones CM, Girdler R, Roe C, Sharpe M, Lawton S, et al. The impact of the COVID92019 pandemic on radiotherapy services in England, UK: a population-based study. Lancet Oncol. $921 \quad 2021 ; 22: 309-20$.

137. Nieder C, Haukland EC, Mannsaker B, Yobuta R. Palliative Radiotherapy During the Last Month of Life: Have COVID-19 Recommendations Led to Reduced Utilization? In Vivo. 2021;35:649-52. of COVID on Radiotherapy Delivery. Curr Oncol. 2020;28:152-8. making for initiation of systemic anticancer treatments in response to the COVID-19 pandemic in 928 England: a retrospective analysis. Lancet Oncol. 2021;22:66-73.

140. Baxter MA, Murphy J, Cameron D, Jordan J, Crearie C, Lilley C, et al. The impact of COVID93019 on systemic anticancer treatment delivery in Scotland. Br J Cancer. 2021;124:1353-6.

931 141. Jazieh AR, Akbulut H, Curigliano G, Rogado A, Alsharm AA, Razis ED, et al. Impact of the 932 COVID-19 Pandemic on Cancer Care: A Global Collaborative Study. JCO Glob Oncol. 2020;142893338.

934 142. Pendyala P, Goglia AG, Mattes MD, Grann A, Huang D, Wagman RT, et al. Impact of the 935 Coronavirus Disease of 2019 Pandemic on Radiation Oncology Clinical Decision Making in a High936 Prevalence Environment. Adv Radiat Oncol. 2021;6:100680. 
medRxiv preprint doi: https://doi.org/10.1101/2022.02.23.22271303; this version posted February 26, 2022. The copyright holder for this preprint (which was not certified by peer review) is the author/funder, who has granted medRxiv a license to display the preprint in

perpetuity.
It is made available under a CC-BY 4.0 International license .

937 143. Kuitunen I, Ponkilainen VT, Uimonen MM, Paloneva J, Launonen AP, Mattila VM. Postponing

938 elective surgery due to COVID-19 did not decrease the oncological surgery rate in Finland. Br J Surg.

$939 \quad 2021 ; 108: \mathrm{e} 191-3$.

940 144. Engelina, S., Watson, L., O’Connell, D., Kennedy, M., Ilchyshyn, A. Effects of COVID-19 on

941 the 2-week-wait dermatology services at a regional centre between 2019 and 2020. Br J Dermatol.

$942 \quad 2020 ; 208-208$.

943 145. Depypere LP, Daddi N, Gooseman MR, Batirel HF, Brunelli A. The impact of coronavirus disease

9442019 on the practice of thoracic oncology surgery: a survey of members of the European Society of

945 Thoracic Surgeons (ESTS). Eur J Cardiothorac Surg. 2020;58:752-62.

946 146. Earnshaw CH, Hunter HJA, McMullen E, Griffiths CEM, Warren RB. Reduction in skin cancer

947 diagnosis, and overall cancer referrals, during the COVID-19 pandemic. $\mathrm{Br} \mathrm{J}$ Dermatol.

$948 \quad 2020 ; 183: 792-4$.

949 147. Muñoz-Martínez S, Sapena V, Forner A, Nault J-C, Sapisochin G, Rimassa L, et al. Assessing

950 the impact of COVID-19 on liver cancer management (CERO-19). JHEP Rep. 2021;3:100260.

951 148. Bogani G, Apolone G, Ditto A, Scambia G, Panici PB, Angioli R, et al. Impact of COVID-19 in

952 gynecologic oncology: a Nationwide Italian Survey of the SIGO and MITO groups. J Gynecol Oncol.

$953 \quad 2020 ; 31: e 92$.

954

149. Sadler D, DeCara JM, Herrmann J, Arnold A, Ghosh AK, Abdel-Qadir H, et al. Perspectives on

955 the COVID-19 pandemic impact on cardio-oncology: results from the COVID-19 International

956 Collaborative Network survey. Cardio-Oncol. 2020;6:1-13.

957

150. Kamarajah SK, Markar SR, Singh P, Griffiths EA, Oesophagogastric Anastomosis Audit Group.

958 The influence of the SARS-CoV-2 pandemic on esophagogastric cancer services: an international survey of esophagogastric surgeons. Dis Esophagus. 2020;33:doaa054. 
medRxiv preprint doi: https://doi.org/10.1101/2022.02.23.22271303; this version posted February 26,2022 . The copyright holder for this preprint (which was not certified by peer review) is the author/funder, who has granted medRxiv a license to display the preprint in It is made available under a CC-BY 4.0 International license.

960 151. Mason SE, Scott AJ, Markar SR, Clarke JM, Martin G, Winter Beatty J, et al. Insights from a

961 global snapshot of the change in elective colorectal practice due to the COVID-19 pandemic. Fong

962 ZV, editor. PLOS ONE. 2020;15:e0240397.

963 152. Frey MK, Ellis AE, Zeligs K, Chapman-Davis E, Thomas C, Christos PJ, et al. Impact of the 964 coronavirus disease 2019 pandemic on the quality of life for women with ovarian cancer. Am J Obstet 965 Gynecol. 2020;223:725.e1-725.e9.

966 153. Martinelli F, Garbi A. Change in practice in gynecologic oncology during the COVID-19 967 pandemic: a social media survey. Int J Gynecol Cancer. 2020;30:1101-7.

968 154. Elkrief A, Kazandjian S, Bouganim N. Changes in Lung Cancer Treatment as a Result of the 969 Coronavirus Disease 2019 Pandemic. JAMA Oncol. 2020;6:1805.

970 155. Reuter-Oppermann M, Müller-Polyzou R, Wirtz H, Georgiadis A. Influence of the pandemic 971 dissemination of COVID-19 on radiotherapy practice: A flash survey in Germany, Austria and 972 Switzerland. Chun S, editor. PLOS ONE. 2020;15:e0233330.

973 156. Bartels MMTJ, Gal R, van der Velden JM, Verhoeff JJC, Verlaan JJ, Verkooijen HM. Impact of 974 the COVID-19 pandemic on quality of life and emotional wellbeing in patients with bone metastases 975 treated with radiotherapy: a prospective cohort study. Clin Exp Metastasis. 2021;38:209-17.

976 157. Ürün Y, Hussain SA, Bakouny Z, Castellano D, Kılıçkap S, Morgan G, et al. Survey of the Impact 977 of COVID-19 on Oncologists’ Decision Making in Cancer. JCO Glob Oncol. 2020;1248-57.

978 158. Baffert K-A, Darbas T, Lebrun-Ly V, Pestre-Munier J, Peyramaure C, Descours C, et al. Quality 979 of Life of Patients With Cancer During the COVID-19 Pandemic. In Vivo. 2021;35:663-70.

980 159. Aeppli S, Eboulet E, Eisen T, Escudier B, Fischer S, Larkin J, et al. Impact of COVID-19 981 pandemic on treatment patterns in metastatic clear cell renal cell carcinoma. ESMO Open. 982 2020;5:e000852. 
medRxiv preprint doi: https://doi.org/10.1101/2022.02.23.22271303; this version posted February 26, 2022. The copyright holder for this preprint (which was not certified by peer review) is the author/funder, who has granted medRxiv a license to display the preprint in It is made available under a CC-BY 4.0 International license .

983 160. Chang, P. J., Jay, G. M., Kalpakjian, C., Andrews, C., Smith, S. Patient and provider-reported 984 satisfaction of cancer rehabilitation telemedicine visits during the COVID-19 pandemic. PM\&R. $985 \quad 2021 ; 13: 1362-8$.

161. Mitchell RD, O’Reilly GM, Mitra B, Smit DV, Miller J, Cameron PA. Impact of COVID-19 State of Emergency restrictions on presentations to two Victorian emergency departments. Emerg Med 988 Australas. 2020;32:1027-33. Lockdown in Surgical Emergency Accesses: Experience of a COVID-19 Hospital. In Vivo. 2020;34:3033-8.

993 effects of the COVID-19 pandemic on physical and mental health in the UK: a population-based study.

994 Lancet Digit Health. 2021;3:e217-30. reasons for primary care visits during the COVID-19 pandemic in a high-COVID region of Canada.

997 Leong C, editor. PLOS ONE. 2021;16:e0255992.

165. Fujisawa, Rie. Impact of the COVID-19 pandemic on cancer care in OECD countries, OECD Health Working Paper. [Forthcoming]. 1002 patients and clinicians. Rheumatology. 2021;keab796. 
medRxiv preprint doi: $h t t p s: / / d o i . o r g / 10.1101 / 2022.02 .23 .22271303$; this version posted February 26, 2022. The copyright holder for this preprint (which was not certified by peer review) is the author/funder, who has granted medRxiv a license to display the preprint in

It is made available under a CC-BY 4.0 International license .

1005 168. Maringe C, Spicer J, Morris M, Purushotham A, Nolte E, Sullivan R, et al. The impact of the

1006 COVID-19 pandemic on cancer deaths due to delays in diagnosis in England, UK: a national,

1007 population-based, modelling study. Lancet Oncol. 2020;21:1023-34.

1008 169. Seretis K, Boptsi E, Boptsi A, Lykoudis EG. The impact of treatment delay on skin cancer in 1009 COVID-19 era: a case-control study. World J Surg Oncol. 2021;19:350.

1010 170. Reuters. Facing new COVID wave, Dutch delay care for cancer, heart patients. [Internet]. 2021

1011 [cited 2022 Jan 18]. Available from: https://www.reuters.com/world/europe/facing-new-covid-wave-

1012 dutch-delay-care-cancer-heart-patients-2021-11-19/

1013 171. Aboulenein A. (Reuters). Overwhelmed by Omicron surge, U.S. hospitals delay surgeries

1014 [Internet]. [cited 2022 Jan 25]. Available from: https://www.reuters.com/world/us/overwhelmed-by-

1015 omicron-surge-us-hospitals-delay-surgeries-2022-01-07/

1016 172. European Cancer Organization. "Time to Act Data Navigator" [Internet]. [cited 2021 Dec 9].

1017 Available from: https://www.europeancancer.org/data-navigator/\#

1018 173. International Agency for Research on Cancer WHO. Global Cancer Observatory [Internet]. [cited

10192022 Jan 8]. Available from: https://gco.iarc.fr/about-the-gco

1020

1021

1022

1023 
medRxiv preprint doi: https://doi.org/10.1101/2022.02.23.22271303; this version posted February 26, 2022. The copyright holder for this preprint (which was not certified by peer review) is the author/funder, who has granted medRxiv a license to display the preprint in It is made available under a CC-BY 4.0 International license.

\section{Supporting information}

1025 S1 Table - Preferred Reporting Items for Systematic reviews and Meta-Analyses extension for

1026 Scoping Reviews (PRISMA-ScR) Checklist

1027 S2 Doc - Search strategy

1028 S3 Table - Data Extraction Form

1029 S4 Table - Characteristics of the studies included in the review, and from which indicators were

1030 extracted and collated

1031

1032 